\title{
Arguments for Marriage in Clement of Alexandria's Stromateis II-III
}

\author{
Jana Plátová \\ (Palacký University, Olomouc)*
}

\begin{abstract}
This article analyses Clement of Alexandria's treatment of authorities in his treatise on marriage (Strom. II, 23, 137, 1 - III, 18, 110,3). It shows that Clement widely quotes not only biblical authorities, but also classical authors; in his practical theology he puts great emphasis primarily on Paul the Apostle, Plato, and Aristotle. The article includes an overview of all of the sources (direct quotes, paraphrases, allusions) that Clement uses in his interpretation and also presents the treatise as a significant source of a large amount of fragments of both classical and early Christian literature.
\end{abstract}

\section{Keywords}

Clement of Alexandria; techniques of quotation; Clement's Stromateis as source of fragments; patristic exegesis of Scripture; sexual ethics; marriage; self-control (enkrateia); heterodox Christians of 2 nd and 3th century

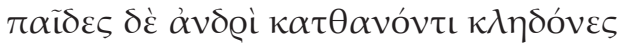

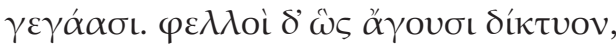

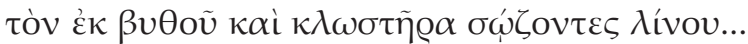
(Aeschylus, Choeph. 505-507 in: Clement of Alexandria, Strom. II, 23, 141, 3)

A discourse on the Christian virtues in the Clement's Stromateis serves as a platform for his thoughts on the usefulness of marriage. Love is, according to Clement, a virtue through which Christians get closer to God, their Creator; thus, it stands on the top of his pyramid of virtues. This love, a reflection of God's love towards men, is not motivated by fear or desire to get favour; it is free from any ulterior motives. This is related to the fact that self-control (enkrateia), too, has a relatively significant place in Clement's classification of virtues and is understood as a state of deliverance from passions, or

\footnotetext{
* This study is a result of the research funded by the Czech Science Foundation as the project GA ČR P401/12/G168 "History and Interpretation of the Bible".

1 For this paper, I used the critical edition of Stählin, Früchtel \& Treu $\left(1985^{4}\right.$ and $\left.1970^{2}\right)$.
} 
apatheia. ${ }^{2}$ Clement includes the treatise on marriage in his meditations because it may seem, at least to some, that "marriage has something to do with pleasure and desire". ${ }^{3}$ Subsequently, Clement attempts to prove that it is not so (or it should not be) using a plenty of, not only Christian, authorities. According to this Alexandrian teacher, marriage is a bond of man and woman based on a free and rational choice, whose greatness lies in the opportunity to bear children which assimilates man to God, the Creator.

The first group of authorities occurs in the end of the Book II of Stromateis ${ }^{4}$ and is crowned by Aristotle (unlike Plato, he is never explicitly mentioned by Clement), ${ }^{5}$ Menander, and Plato. Clement shares with these authorities the conviction that the primary purpose of marriage is to produce children by which, according to Plato, one secures for himself a kind of immortality. Then he cites Gen 20:12 to give evidence on the prohibition of marrying a sister as well as, little surprisingly, to defend a free choice of woman when entering marriage. Right after that, a wide range of ideas on marriage follow, beginning with the contemptuous presumptions of Democritus and Epicurus, followed by the indifferent Stoic attitude, and concluding with the unambiguously positive assessment of the Peripatetic School. Although Clement considers most of the abovementioned approaches to be more or less right, he claims that many of them only proclaimed these ideas, while, in fact, they remained the slaves of their own pleasures, ${ }^{6}$ therefore, their praxis prove the opposite. It is not clear whether Clement means this criticism to fall also on Plato and Aristotle, as he, immediately after that, refers to "those who appreciate marriage" and paraphrases their ideas on marriage in the Republic and the Laws. ${ }^{7}$ As will be shown later, Clement's theological conception appears to fall more in line with the one of Plato.

In the following paragraph, Clement recapitulates the aforesaid reasons for the usefulness of marriage to add a further argument - the consummation of $\operatorname{cosmos}^{8}{ }^{8}$ It is not certain whether he was inspired in this by his predecessor Philo of Alexandria; nevertheless, it seems probable with respect to the fact that he draws on him in other places, too. ${ }^{9}$

The authorities he includes afterwards only confirm the aforesaid advantages of marriage, especially the opportunity to leave behind a progeny. Homer ${ }^{10}$ and Menander ${ }^{11}$ are cited twice in this context, once he cites Sophocles (but his source is, in fact, Aeschylus), ${ }^{12}$

2 For the detailed research on this originally Stoic term and its Christian understanding in Clement, see Šedina (2006: pp. 59-74) and Černušková (2011: pp. 45-54).

3 Strom. II, 23, 137, 1. Here and also elsewhere, I cite from the translation of Ferguson (1991).

4 Cf. Strom. II, 23, 137, 1-138, 5. For the detailed overview of cited/paraphrased authors, see Appendix.

5 For Clement's inspiration by Aristotle, see the fundamental study of Clark (1977).

6 Cf. Strom. II, 23, 138, 6.

7 Cf. Strom. II, 23, 139, 3-5.

8 Cf. Strom. II, 23, 140, 1.

9 For Clement's inspiration by Philo, see van den Hoek (1988) who, however, does not state this place.

10 Cf. Strom. II, 23, 140, 1 and 143, 1.

11 Cf. Strom. II, 23, 141, 1 and 142, 3.

12 Cf. Strom. II, 23, 141, 3. 
and once "noble Plato" is mentioned. ${ }^{13}$ The next argument is introduced by a reference to Genesis, namely that woman is man's helper in many practical aspects of life, especially in disease and old age. ${ }^{14}$

In the very conclusion of Book II, Clement resides from citing the authorities for a while to put forward his own idea to the reader: he presents the specific features of marriage based on $\log o s,{ }^{15}$ while in his argumentation he calculates upon the ambiguity of the Greek word. On the one hand, this enables him to presume that there is a rational (or reasonable) motivation to enter such a union, not only a temporary desire or passion. On the other hand, it serves as a foreground for the development of marital ethics inspired by Logos - the Word which, in agreement with the theology of the Gospel according to John, speaks to men through the Scripture, i.e. both the Law and the gospels. Throughout this discourse, Clement cites several passages of the Old Testament and the gospels specifying the relationship of man and woman ${ }^{16}$ but, surprisingly, also Euripides and Hesiod. The words of the former are incorporated to praise the chastity of woman (Polyxena) even in the extreme situation of her own death, while from the latter he borrows a verse calling upon prayer at any time of the day. ${ }^{17}$ Clement's rhetoric in this section is, however, not limited to the cited authorities - the author presents his own conception of marriage as "a holy (God's) image" whose purity should be pursued whole life. $^{18}$

The treatise on marriage seems to be concluded by this which is also suggested by the fact that it is the end of Book II of Stromateis. The following book would certainly deserve a new, nobler, more spiritual, and pious topic, as it would be fit for the author's more mature work. However, no treatise on Christian mysticism follows. On the contrary, almost a third of Book III is dedicated to sometimes even toilsome polemics on various Christian, would-be Christian, or explicitly non-Christian views on human sexuality Clement finds necessary to amend.

First, the supporters of Basilides ${ }^{19}$ are present, then the disciples of Carpocrates and Epiphanes, ${ }^{20}$ the followers of Marcion of Sinope, ${ }^{21}$ and, finally, the Nicolaites, the Prodiceans, and the Antitactists. ${ }^{22}$ Briefly speaking, Clement rebukes two extreme positions: either the exaggerated abstinence preferring celibacy from the marital bond which, in some cases, even despises sexuality as such, or, conversely, the excessive liberty in sexual intercourse. Therefore, he sums up his argumentation into two chapters in

\footnotetext{
13 Cf. Strom. II, 23, 141, 5.

14 Cf. Strom. II, 23, 140, 2-141, 2.

15 Cf. Strom. II, 23, 143, 1 ff.

16 Cf. Strom. II, 23, 144, 4-147, 4.

17 Cf. Strom. II, 23, 144, 2 and 145, 1.

18 Cf. Strom. II, 23, 145, 1-2.

19 Cf. Strom. III, 1, 1, 1-4, 3.

20 Cf. Strom. III, 2, 5, 1-11, 2.

21 Cf. Strom. III, 3, 12, 1-4, 25, 4.

22 Cf. Strom. III, 4, 25, 5-39, 3.
} 
which he argues against his adversaries formally divided into two groups: against the Libertinism and the Encratism. ${ }^{23}$ The nature of Clement's argumentation in Stromateis III at the first glance differs from his discourse in the end of Book II. Except for the section dedicated to Marcion and his followers, Clement does not at all cite classical authorities; on the contrary, he includes relatively long passages from the works of today already forgotten authors - the representatives of those lines of thoughts Clement polemizes with, sometimes in friendly terms, sometimes harshly. It is thanks to this polemics that we possess several fragments of the early Christian heterodox treatises: ${ }^{24}$ a quotation of an unknown work of Basilides explaining the alternative reading of Matt 19:10-12;25 a fragment of the Ethics ascribed to Basilides' son and disciple named Isidore; ${ }^{26}$ an extensive passage from Epiphanes' book On Righteousness $;{ }^{27}$ sporadic statements of Nicolaus and Matthias, the two figures only marginally appearing in the New Testament; ${ }^{28}$ a quotation of an unknown (perhaps Gnostic) apocryphal work; ${ }^{29}$ and, last but not least, several fragments attesting the dialogue of Jesus with his disciple Salome according to the apocryphal Gospel according to the Egyptians. ${ }^{30}$

Before I proceed to the last and de facto fundamental part of Clement's treatise on marriage, the exception mentioned above is worth attention, namely Clement's polemics with Marcion's disciples who are said to distort the teaching of Greek authors. ${ }^{31}$ As is well known, Marcion based his teaching on the implacability between the cruelty of the Old Testament and the kindness of Jesus' teaching. Thus, there is a distinction between de facto two deities: the "rightful" Demiurge (whom he refused in his conception of Christianity) and the merciful God of the New Testament. Clement states that the followers of Marcion reject the natural state, including human sexuality, created by the Demiurge and, from the same reason, they also reject marriage. ${ }^{32}$ Furthermore, Clement states that Marcion's disciples took over the idea that birth was something wrong from the Greek philosophers who, however, according to Clement, did not consider birth to be something fundamentally wrong but only regarded it wrong "in relation with the soul which has already recognized the truth". ${ }^{33}$ In this section, Clement includes a long series of classical quotations to prove that not even the old poets, philosophers, and play-

23 Cf. Strom. III, 5, 40, 1-6, 45, 1; cf. also III, 7, 60, 1-67, 2.

24 Le Boulluec (1985) remains the most complete study on this topic.

25 Cf. Strom. III, 1, 1, 1-2, 1. The fragments of this ancient Gnostic were collected and commented in detail by Löhr (1996) in which the relevant text is the fragment No. 6 (pp. 101-122).

26 Cf. Strom. III, 1, 2, 2-3, 2.

27 Cf. Strom. III, 2, 6, 1-8, 3; 9, 3.

28 Cf. Strom. III, 4, 25, 5-26, 3. For the figure of Matthias in the early Christian tradition and the possibility of the preservation of a gospel bearing his name, see Plátová (2006: pp. 69-80).

29 Cf. Strom. III, 4, 29, 2.

30 Cf. Strom. III, 6, 45, 3; 9, 63, 1-66, 2; 13, 92, 2-93, 1. For the Gospel of the Egyptians, see Markschies (2012: pp. 661-682); a Czech translation in Dus \& Pokorný (2001: pp. 224-226).

31 Cf. Strom. III, 3, 12, 1-4, 25, 4.

32 Cf. Strom. III, 3, 12, 1-2.

33 Cf. Strom. III, 3, 13, 1. 
wrights of tragedies regarded birth and life in this world a walk in the park. Heraclitus is cited first; then Empedocles, Homer, and Euripides are repeatedly referred to; further, he also states Theognis of Megara, Herodotus, Philolaus, and Pindar; finally, he cites the extensive passages from his favourite source Plato. ${ }^{34}$ Clement notes that, according to several of these, it might seem at the first sight that the earthly life is only a misery; nevertheless, it does not imply that these authors despised birth and natural state as such. Plato's statements are cited as an example par excellence - although he describes the earthly life as a punishment suffered by soul incarcerated in body, he, at the same time, "speaks reverently about the world" when he claims that "all that is good is got from the supreme disposer". ${ }^{35}$ Therefore, Clement concludes that it is more than clear Marcion took over the teaching of Plato "without acknowledgement or understanding". ${ }^{36}$

After this extensive treatment of various lines of thoughts that Clement obviously encountered in his time either personally, or through religious treatises, he finally overcomes all obstacles which impeded him from presenting his own conception of Christian sexuality, marriage, and the role of self-control (enkrateia) in it. He begins with his own definition of enkrateia which he claims to be different from the one treated by Greek philosophers. However, a more detailed analysis of this place reveals that Clement's definition strikingly resembles Aristotle's definition in his Nicomachean Ethics. ${ }^{37}$ The point is that a moderate man is, by God's grace, equipped not only to control his desires, but also to not feel it at all. Clement's only novum when compared to Aristotle is that he also adds a note on how to achieve such self-control, i.e. solely by God's grace. Clement states two examples of the people gifted with the divine self-control: Moses and Jesus, while the former is supported by an argument from the Scripture, whereas the latter surprisingly not from a gospel, but from Valentinus' Epistula ad Agathopoda. ${ }^{38}$ Apart from these, he bases his argumentation also on several passages from Paul's epistles. ${ }^{39}$ Perhaps in order to clarify his understanding of self-control, he then brings attention to the twisted life of the members of some sects again. These are said either to stupidly and impiously cultivate self-control without reason out of their hatred for body, or to teach moral indifference by distorting some passages of the Scripture. ${ }^{40}$

Clement finds neither of these extremes acceptable; he explicitly and repeatedly warns against the idea that marriage is a $\sin .{ }^{41}$ The freedom to choose either status is essential

34 Cf. Strom. III, 3, 14, 1-23, 3; for the complete overview of the authors, see Appendix.

35 Strom. III, 3, 19, 4-5 (with the quotation of Plato, Polit. 273b-c).

36 Strom. III, 3, 21, 2.

37 Cf. Strom. III, 7, 57, 1 and Aristotle, Eth. Nic. 1151 b33 (however, Clement does not state his source here).

38 Cf. Strom. III, 7, 57, 3 and 59, 3.

39 Rom, 1 Cor, Phil, Gal and Heb (several passages imply that Clement regarded Epistle to the Hebrews an authentic work of Apostle Paul: cf. Strom. II, 22, 136, 2-3; VI, 8, 62, 2 and Adumbr. I/ad 1 Pet 5:13/. This conviction, probably taken from Clement's teacher Pantaenus, is shared also by Eusebius of Caesarea, Hist. eccl. VI, 14, 2-4 = Hyp., Fr. 22); for the detailed list of the cited passages from the New Testament, see Appendix.

40 Strom. III, 7, 60, 1-4; 8, 61, 1-9; 67, 2.

41 Cf. Strom. III, 9, 67, 1; 12, 89, 1 and 90, 5. 
for Clement with emphasis put on its free realization or, in other words, on the purity and sincerity of the decision which should not be made under the pressure of outer circumstances and ulterior dishonest or unmanly motives. ${ }^{42}$ To support the institution of marriage as a union blessed and sanctified by God, Clement states an argument from the gospel, namely the Jesus' word: "For where two or three gather in my name, there am I with them." 43

In the last section of Book III, Clement presents several arguments from the Scripture applicable both in the potential reader's discussion with the members of heterodox sects as well as in one's own marital spirituality. Just like in the previous sections (and de facto the whole Stromateis), he prefers The Gospel according to Matthew and The Pauline Epistles. ${ }^{44}$ While interpreting the statements of Paul in Rom, 1 and 2 Cor dealing with the spouses (with a special attention paid to 1 Cor 7), Clement polemizes with Tatian and John Cassian once again using the citations from their lost works: Tatian's On Training Following the Savior ${ }^{45}$ and Cassian's On Self-Control or Celibacy. ${ }^{46}$ It is obvious that Clement very much cares about purifying marriage in the eyes of some credulous Christians who let themselves be led astray by the seemingly devout preaching, which regards marriage as "a union stigmatised by downfall impeding the access to God" 47 and which, in fact, deviates from the gospel.

The last lines of Book III can be regarded as a kind of epilogue and, at the same time, a recapitulation and a summary of what was explicitly, or implicitly, said above. According to Clement, no man should set himself up over the others; on the contrary, one should rather be grateful for the life path that was chosen for him and pursue rightfulness to achieve salvation. ${ }^{48}$ The very last verses Clement includes to support his argumentation are, unsurprisingly, taken from the New Testament: "Everything is pure to those whose hearts are pure" 49 and "just as he who called you is holy, so be holy in all you do". ${ }^{50}$

42 Cf. Strom. III, 9, 67, 1-2.

43 Matt 18:20, 20 in Strom. III, 10, 68, 1 ff. Associating this verse with Christian family is absolutely unique in the history of biblical exegesis; up to the $20^{\text {th }}$ century, Jesus' presence was tied to the clerical societies represented especially by monks or friars. For more information on this, see e.g. Luz (1997: pp. 37-60, especially 53 ff.) or Rossé (1972 and 1987).

44 Cf. Strom. III, 11, 71, 1-17, 104, 5.

45 Cf. Strom. III, 12, 81, 1-2.

46 Cf. Strom. III, 13, 91, 1-92, 2.

47 Strom. III, 12, 81, 1.

48 Cf. Strom. III, 18, 105, 1-110, 3.

49 Titus 1:15 in Strom. III, 18, 109, 1.

501 Pet 1:14-16 in Strom. III, 18, 110, 1-2. 


\section{Conclusion}

What can be noticed from the closer reading of Clement's argumentation? How does this author, who cites or paraphrases over 350 diverse authors and treatises in his discourse, work with these authorities?

1. Clement's choice and ordering of the authorities is not random. In the introductory section, he pursues to present the advantages of marriage; thus, he mostly cites the classical authors, while, sporadically, he also includes passages from the Bible. The essential part of the treatise is dedicated to the polemics with the heterodox sects - Clement explicitly states the erroneous ideas of these and, consequently, reacts to them using Plato's teaching and the arguments from the Scripture. In the last section, he exclusively includes the passages from the Scripture. This tendency, namely to present first the arguments taken from classical literature followed by those stated in the Scripture in the conclusion, is typical of Clement. In the beginning of Stromateis VII, ${ }^{51}$ he even declares this to be his main methodological conception.

2. The aforesaid overview reveals that Clement appeals to the Bible altogether 275 times (191 times to the New Testament and 84 times to the Old Testament), whereas the classical authors are referred to only 75 times, while the remaining 33 citations are taken from various (often anonymous) early Christian authors, including Paul's contemporary Philo of Alexandria. The fact that the works of classical authors are cited more or less as frequently as the Old Testament well agrees with the author's conviction that Greek philosophy (in a broader sense of the word) has the same origin and purpose as the Hebrew Scriptures. Just like the Hebrew Law, it is a God's creation given to the people (whether pagans or the Jewish) to "raise" them and prepare them for the coming of Christ. ${ }^{52}$

3. Some authors are explicitly mentioned by Clement (most of the ancient poets, Plato, Apostle Paul), while others are not stated at all (Aristotle, Philo), even though he does not hesitate to take over their formulations. He, however, always cites his adversaries (i.e. the representatives of the heterodox Christian sects) verbatim. As for the authors close to him, he often prefers to paraphrase them or hints at them in a more or less obscure way (typically at the New Testament). This practice is completely in line with the conclusions made by Annewies van den Hoek in her study - Clement frequently omits to state his source when he refers to those authors he either immediately draws on or who play an essential role in his theological conception. Therefore, the direct proportion, i.e. the more citations, the more important author, does not apply here. ${ }^{53}$

It is obvious that Clement's ethics stems primarily from the Bible; however, regarding the questions of sexuality and marriage, he gets his inspiration especially from Apostle Paul's First Epistle to the Corinthians. Simultaneously, it has been shown that, in some of

51 Cf. Strom. VII, 1, 1, 2-3; see also Strom. III, 11, 71 ff. or Quis dives 37,1-38,4.

52 Cf. Strom. I, 5, 28, 2-3, and others.

53 Cf. van den Hoek (1996: pp. 223-243). 
the key sections where Clement formulates the theoretical background of his morals, the non-Christian authorities like Plato, Aristotle, and Philo have their word, as well. Clement's main argument for marriage used in the polemics with the supporters of Christian encratism is taken especially from Plato. Nevertheless, it must be said that the presence of classical literature quotations in the key sections of Clement's argumentation does not imply that Clement considers the Scripture to be bottom of the pile. The Old Testament precepts, Jesus' sayings in the gospel, as well as the formulations of Apostle Paul are more than mere statements to him. There is no need to question their truthfulness, as they represent the "unshakable criterion" which surpasses human knowledge, is received in faith, and accessible to all those who want and make appropriate effort to attain it. ${ }^{54}$

As illustrated above, the meditations on marital life occupy a large part of Clement's work - one book out of the seven books of Stromateis did not suffice him. One may argue that it is too much and perhaps it is right. The author himself admits in the conclusion of Book III that "our critique of the hypocritical pretenders to knowledge has gone beyond what is necessary and stretched out our discourse to a considerable length". ${ }^{55}$ Nevertheless, our collections of fragments and the collective apocryphal editions would be severely depleted without Clement's defence of marriage and his extensive polemics on enkrateia.

\section{Bibliography}

\section{Critical editions and translation of primary sources:}

Ferguson, J. (Transl.). (1991). Clement of Alexandria: Stromateis. Books one to three. Washington, D.C.: The Catholic University of America Press.

Stählin, O., Früchtel, L., \& Treu, U. (Eds). (1985²). Clemens Alexandrinus: Opera (Vol. II; Die griechischen christlichen Schriftsteller der ersten drei Jahrhunderte, 15). Berlin: Akademie-Verlag.

Stählin, O., Früchtel, L., \& Treu, U. (Eds). (1970²). Clemens Alexandrinus: Opera (Vol. III; Die griechischen christlichen Schriftsteller der ersten drei Jahrhunderte, 17). Berlin: Akademie-Verlag.

Šedina, M., Černušková, V., \& Plátová, J. (Transl. \& Notes). (2006). Klement Alexandrijský: Stromata, II-III. Praha: Oikúmené.

\section{Secondary sources:}

Clark, E. A. (1977). Clement's Use of Aristotle. The Aristotelian Contribution to Clement of Alexandria's Refutation of Gnosticism. New York: E. Mellen Press.

Černušková, V. (2011). Apatheia. In V. Černušková, \& J. Plátová (Transl. \& Notes), Klement Alexandrijský: Stromata, VII (pp. 45-54). Praha: Oikúmené.

54 Cf. Strom. II, 2, 7, 2; 4, 12, 1 and 15, 5.

55 Strom. III, 18, 110, 3. 
Dus, J. A., \& Pokorný, P. (2001). Neznámá evangelia. Novozákonni apokryfy (Vol. I). Praha: Vyšehrad. Hoek, A. van den (1988). Clement of Alexandria and His Use of Philo in the Stromateis. Leiden-Boston: Brill.

Hoek, A. van den (1996). Techniques of Quotation in Clement of Alexandria. A View of Ancient Literary Working Methods. Vigiliae Christianae, 50, 223-243.

Le Boulluec, A. (1985). La notion d'hérésie dans la littérature grecque (II-III siècles). Tome I: De Justin à Irénée; Tome II: Clément d'Alexandrie et Origène (Collection des Études Augustiniennes, Série Antiquité, 110-111). Paris: Institut des Études Augustiniennes.

Löhr, W. A. (1996). Basilides und seine Schule (Wissenschaftliche Untersuchungen zum Neuen Testament, 83). Tübingen: Mohr Siebeck.

Luz, U. (1997). Das Evangelium nach Matthäus (Evangelisch-katholischer Kommentar zum Neuen Testament, 1, 3). Zürich: Benzinger.

Markschies, Ch. (2012). Das Evangelium nach den Ägyptern. In Ch. Markschies, \& J. Schröter (Eds.), Antike christliche Apokryphen in deutscher Übersetzung, I: Evangelien und Verwandtes (Vol. I; pp. 661-682). Tübingen: Mohr Siebeck.

Plátová, J. (2006). Matějovy Tradice. In H. Krmíčková, A. Pumprová, D. Růžičková, \& L. Švanda (Eds.), Querite primum regnum Dei: Sbornik př́spěvků k poctě Jany Nechutové (pp. 69-80). Brno: Matice moravská.

Rossé, G. (1972). Gesú in mezzo. Matteo 18, 20 nell'esegesi contemporanea. Roma: Città Nuova.

Rossé, G. (1987). L'ecclesiologia di Matteo. Interpretazione di Mt. 18, 20. Roma: Città Nuova.

Šedina, M. (2006). Apatheia božského bytí. In M. Šedina, V. Černušková, \& J. Plátová (Transl. \& Notes), Klement Alexandrijský: Stromata, II-III. (pp. 59-74). Praha: Oikúmené.

Mgr. Jana Plátová, Ph.D. / Jana.Platova@upol.cz

Centre for Patristic, Medieval and Renaissance Texts

Palacký University Olomouc, Sts Cyril and Methodius Faculty of Theology

Univerzitní 22, 77111 Olomouc, Czech Republic 


\section{Appendix}

The list of cited and paraphrased authorities in Clement's treatise on marriage (Strom. II, 23, 137, 1 - III, 18, 110, 3): ${ }^{56}$
II, 23, 137, 1
II, 23, 137, 2
II, 23, 137, 3
II, 23, 137, 4
II, 23, 138, 1
II, 23, 138, 2
II, 23, 138, 3
II, 23, 138, 3-4
II, 23, 138, 5
II, 23, 138, 5
II, 23, 139, 2
II, 23, 139, 3
II, 23, 139, 3
II, 23, 139, 5
II, 23, 140,1
II, 23, 140, 1
II, 23, 140, 1
II, 23, 140, 2
II, 23, 141, 1
II, 23, 141, 3
II, 23, 141, 4
II, 23, 141, 4
II, 23, 141, 5
II, 23, 141, 5
II, 23, 142, 3
II, 23, 143, 1
II, 23, 143, 2
II, 23, 144, 1
II, 23, 144, 2
II, 23, 144, 4
II, 23, 145,1
II, 23, 145, 3
II, 23, 146, 1
II, 23, 146, 2
II, 23, 147, 1
II, 23, 147, 1
II, 23, 147, 3
II, $23,147,4$
III, 1, 1, 1

Aristotle, Pol. 1252a26

Menander, Fr. 682 (Koerte) / 720 (Kock)

Aristotle, Rhet. 1383b12n.

Aristotle, Pol. 1334b34-36

Gen 20:12

Plato, Leg. 721c; 773e-774. 776b

Democritus, Fr. B276-B278 (Diels-Kranz)

Epicurus, Fr. 526 (Usener)

Stoics: Chrysippus, Fr. 163 (Arnim)

Peripathetics, unknown fragment

Tob 4:15

Aristotle, Pol. $1334 \mathrm{~b} 29$

Gen 1:28

Plato, Leg. 721c

Philo, Quod Deus sit immut. 16-19

Homer, Il. II, 701

Homer, $I l$. XXII, 496

Gen 2:18

Menander, Fr. 276 (Koerte) / 325,1-4 (Kock)

Aeschylus, Choeph. 505-507 (by mistake cited as Sophocles)

Aristo of Chios, Fr. 400 (Arnim)

Plutarch, Lys. 30 (Mor. 493e)

Philo, De vita cont. 62

Plato, Leg. 774a-c; 838e

Menander, Fr. 939 (Koerte) / 1085 (Kock)

Homer, Od. VI, 181-182

Philo, De ebrietate, Fr. 6

Plutarch, Mor. 142c

Euripides, Hec. 569-570

Isa 50:1 (Bar 4:6)

Hesiod, Op. 339

Matt 5:32 (19:9)

1 Tim 5:13

Matt 5:32 par.

Lev 21:9

Deut 22:24

Ezek 33:1

Luke 12:48

Valentinus, unknown fragment
C

C

C

C

OT

C

C

C

C

C

OT

C

OT

C

JAChrL

C

C

OT

C

C

C

C

JAChrL

C

C

C

JAChrL

C

C

OT

C

NT

NT

NT

OT

OT

OT

NT

JAChrL

$56 \mathrm{C}=$ Classics; OT = Old Testament (including apocrypha and LXX); NT = New Testament; JAChrL = Jewish and Ancient Christian Literature. 


\begin{tabular}{|c|c|c|}
\hline III, $1,1,1$ & Matt 19:10-12 & NT \\
\hline III, $1,1,1-2,1$ & Basilides, Fr. 6 (Löhr) & JAChrL \\
\hline III, $1,2,1$ & 1 Cor $7: 9$ & NT \\
\hline III, 1, 2, 2-3, 2 & Isidor, Ethica (unknown fragment) & JAChrL \\
\hline III, $1,3,4$ & 2 Cor 11:13-15 & NT \\
\hline III, $1,3,3$ & Gal 6:2 & NT \\
\hline III, $1,3,3$ & 1 Cor $7: 9$ & NT \\
\hline \multicolumn{2}{|c|}{ III, 2, 6, 1-8, 3; 9, 3 Epiphanes, On Righteousness (unknown fragment) } & JAChrL \\
\hline III, $2,7,2$ & Rom 7:7 & NT \\
\hline III, $2,8,4$ & Exod 20:13 (Matt 5:28) & OT \\
\hline III, $2,8,5$ & Exod $20: 17$ bis $(9: 1)$ & OT \\
\hline III, $2,8,6$ & Gen 17:5 (Rom 4:16-17) & OT \\
\hline III, $2,9,1$ & Lev 20:10 (Deut 22:22) & OT \\
\hline III, $2,9,1$ & Matt 5:28 & NT \\
\hline III, $2,10,1$ & Euripides, Fr. 895 (Nauck) & $\mathrm{C}$ \\
\hline III, $2,10,2$ & Plato, Resp. 457c nn. & $\mathrm{C}$ \\
\hline III, $2,11,1$ & Xanthos, Fr. 31 (Jacoby) / 28 (Müller) & $\mathrm{C}$ \\
\hline III, $2,11,2$ & Jude $8-16$ & NT \\
\hline III, $3,14,1$ & Heraclitus, Fr. B20 (Diels-Kranz) & $\mathrm{C}$ \\
\hline III, 3, 14, 2 & Empedocles, Fr. B118 (Diels-Kranz) & $\mathrm{C}$ \\
\hline III, $3,14,2$ & Empedocles, Fr. B125 (Diels-Kranz) & $\mathrm{C}$ \\
\hline III, 3, 14, 2 & Empedocles, Fr. B124 (Diels-Kranz) & $\mathrm{C}$ \\
\hline III, $3,14,3$ & Orac. Sibyll. Fr. 1,1 (Geffcken) & JAChrL \\
\hline III, $3,14,3$ & Homer, Od. XVIII, 130 & $\mathrm{C}$ \\
\hline III, $3,15,1$ & Theognis, Eleg. 425-427 & $\mathrm{C}$ \\
\hline III, $3,15,2$ & Euripides, Fr. 449 (Nauck) & $\mathrm{C}$ \\
\hline III, $3,15,3$ & Euripides, Fr. 638 (Nauck) & $\mathrm{C}$ \\
\hline III, $3,16,1$ & Herodotus, Hist. I, 31-32 & $\mathrm{C}$ \\
\hline III, $3,16,2$ & Homer, $I l$. VI, 146 & $\mathrm{C}$ \\
\hline III, $3,16,3-4$ & Plato, Crat. $400 \mathrm{bc}$ & $\mathrm{C}$ \\
\hline III, $3,17,1$ & Philolaus, Fr. B14 (Diels-Kranz) & $\mathrm{C}$ \\
\hline III, $3,17,2$ & Pindar, Fr. 137 (Snell) & $\mathrm{C}$ \\
\hline III, $3,17,3$ & Plato, Phd. 69cd & $\mathrm{C}$ \\
\hline III, $3,17,4$ & Plato, Phd. 66b & $\mathrm{C}$ \\
\hline III, $3,17,5$ & Plato, Phd. 64a & $\mathrm{C}$ \\
\hline III, $3,18,1$ & Plato, Phd. 65c & $\mathrm{C}$ \\
\hline III, $3,18,2$ & Rom 7:24 & NT \\
\hline III, $3,18,4$ & Plato, Resp. 328d & $\mathrm{C}$ \\
\hline III, $3,18,5$ & Plato, Resp. 329c & $\mathrm{C}$ \\
\hline III, $3,19,1$ & Plato, Phd. 62b & $\mathrm{C}$ \\
\hline III, 3, 19, 2 & Plato, Phd. 114b-c & $\mathrm{C}$ \\
\hline III, $3,19,3$ & Plato, Phd.62 b & $\mathrm{C}$ \\
\hline III, $3,19,5$ & Plato, Polit. 273b-c & $\mathrm{C}$ \\
\hline III, $3,20,1$ & Plato, Polit. 273b & $\mathrm{C}$ \\
\hline III, 3, 20, 2 & Plato, Leg. 653c-d & $\mathrm{C}$ \\
\hline III, $3,20,3$ & Plato, Epin. 973d & $\mathrm{C}$ \\
\hline
\end{tabular}




\begin{tabular}{|c|c|c|}
\hline III, $3,21,1$ & Heraclitus, Fr. B21 (Diels-Kranz) & $\mathrm{C}$ \\
\hline III, $3,21,1$ & Plato, Gorg. 492e & $\mathrm{C}$ \\
\hline III, $3,21,1$ & Pythagoras, unknown fragment & $\mathrm{C}$ \\
\hline III, 3, 22, 2 & Euripides, Fr. 908 (Snell) & $\mathrm{C}$ \\
\hline III, $3,22,3$ & Euripides, Fr. 908a (Snell) & $\mathrm{C}$ \\
\hline III, $3,22,4$ & Euripides, Fr. 908b (Snell) & $\mathrm{C}$ \\
\hline III, $3,23,1$ & Euripides, Iph. Aul. 161-163 & $\mathrm{C}$ \\
\hline III, 3, 23, 2 & Euripides, Antiop. Fr. 211 & $\mathrm{C}$ \\
\hline III, $3,23,3$ & Euripides, Hiketides 269-270 & $\mathrm{C}$ \\
\hline III, 3, 24, 1-2 & Pythagorean school, unknown fragment & C \\
\hline III, $3,24,2$ & Empedocles, Fr. B141 (Diels-Kranz) & $\mathrm{C}$ \\
\hline III, 3, 24, 3 & Theophrastus, De caus. plant. V, 15, 1 & C \\
\hline III, $4,25,3$ & Matt 8:22 (Luke 9:60) & NT \\
\hline III, $4,25,4$ & Kol 3:5 (Rom 6:10-16; 1:8) & NT \\
\hline III, $4,25,7$ & Nicolaus, unknown fragment 1 & JAChrL \\
\hline III, 4, 26, 2 & Matt 6 :24 (Luke 16:13) & NT \\
\hline III, $4,26,2$ & Nicolaus, unknown fragment 1 & JAChrL \\
\hline III, $4,26,3$ & Traditiones / Evangelium of Matthias, Fr. 2 & JAChrL \\
\hline III, $4,27,1$ & Plato, Symp. 180e nn. & $\mathrm{C}$ \\
\hline III, $4,27,3$ & Nicolaus, unknown fragment 2 & JAChrL \\
\hline III, $4,28,1-2$ & Eph 4:20-24 & NT \\
\hline III, $4,28,3$ & Plato, Tht. $176 \mathrm{a}-\mathrm{b}$ & C \\
\hline III, $4,28,4-5$ & Eph 5:1-4 & NT \\
\hline III, $4,28,6$ & Eph 5:5-11 & NT \\
\hline III, 4, 29, 2 & fragment of unknown apocryphon & JAChrL \\
\hline III, $4,30,1$ & Matt 12:8 (Marc 2:28; Luke 6:5) & NT \\
\hline III, $4,30,1$ & Prodicus, unknown fragment & JAChrL \\
\hline III, $4,30,3$ & John 8:34 & NT \\
\hline III, $4,31,1$ & Matt 5:28 & NT \\
\hline III, $4,31,3$ & Luke 16:12 & NT \\
\hline III, $4,32,1$ & Num 25:8-13 & OT \\
\hline III, 4, 32, 2 & 1 John 1:6f & NT \\
\hline III, 4, 33, 3 & Matt 5:20 & NT \\
\hline III, $4,33,4$ & Dan 1:10-16 & OT \\
\hline III, $4,33,4$ & Ps 118 (119):9f & OT \\
\hline III, $4,33,5$ & Jer 10:2 & OT \\
\hline III, 4, 34, 2 & Luke 11:40 & NT \\
\hline III, 4, 34, 2 & Plato, Phil. 35c & $\mathrm{C}$ \\
\hline III, $4,34,3$ & Matt 13:25 & NT \\
\hline III, $4,34,4$ & Matt 20:14 (Deut 5:18) & NT \\
\hline III, $4,35,1$ & Matt 7:15-16 & NT \\
\hline III, $4,36,1$ & Matt 5:44 (Luke 6:27-28.35) & NT \\
\hline III, $4,36,1$ & Luke 12:58 & NT \\
\hline III, $4,36,4$ & Matt 5:16 & NT \\
\hline III, $4,36,5$ & 2 Macc 5:21 & OT \\
\hline III, $4,36,5$ & Exod 20:14 (Deut 5:18) & OT \\
\hline
\end{tabular}


III, 4, 36, 5

III, 4, 37, 1

III, 4, 37, 2

III, 4, 37, 2

III, 4, 38, 2

III, $4,38,4$

III, $4,38,4$

III, $4,39,1$

III, 4, 39, 3

III, $5,40,4$

III, $5,40,5$

III, $5,41,3$

III, 5, 42, 2

III, $5,42,2$

III, $5,42,4$

III, 5, 42, 5

III, 5, 42, 6

III, $5,43,3$

III, $5,43,4$

III, $5,43,5$

III, 5, 44, 1

III, $5,44,3$

III, $5,44,5$

III, $6,45,2$

III, $6,45,3$

III, $6,45,3$

III, $6,46,2$

III, $6,46,2$

III, $6,46,3$

III, $6,46,4$

III, $6,46,4$

III, $6,47,1$

III, 6, 47, 2

III, 6, 47, 3

III, $6,47,3$

III, $6,48,3$

III, 6, 49, 2

III, 6, 49, 4

III, $6,49,4$

III, $6,49,5$

III, $6,49,6$

III, $6,49,6$

III, $6,50,1$

III, $6,50,2$

III, $6,51,1$

III, $6,51,2$
Herodotus, Hist. VII, 54

C

Gen 1:28-29

OT

Exod 21:24.37

OT

Deut 6:5; 27:15

OT

Mal 3:15

OT

Jer 12:1

OT

Mal 3:15

OT

Rom 3:8

Mal 2:17

Matt 12:8

1 Cor 6:12 (10:23)

Gal 5:13

NT

OT

NT

NT

NT

Hesiod, Op. 211

C

C

C

C

NT

NT

NT

NT

NT

JAChrL

NT

NT

1 John 2:18-19

Gospel according to the Egyptians, Fr. A (Schneemelcher)

JAChrL

JAChrL

Philo, De decal. 58

Matt 5:17

Rom 2:14-15

NT

NT

Gen 18:27

Matt 5:28

OT

NT

Matt 19:6

NT

1 Cor 7:14

NT

NT

Matt 19:3-9; 5:32

NT

NT

1 Cor 6:13

NT

Rom 14:17

$\mathrm{OT}$

Prov 3:34

NT

NT

Matt 24:37-39

NT

NT

NT

NT

NT

C

NT 
III, $6,51,3$

III, $6,51,3$

III, $6,51,3$

III, 6, 52, 1

III, $6,52,1$

III, $6,52,3$

III, $6,52,4$

III, $6,53,1$

III, $6,53,2$

III, $6,53,3$

III, $6,53,4$

III, $6,53,4$

III, $6,53,5$

III, 6, 54, 1

III, 6, 54, 1

III, 6, 54, 3

III, $6,54,4$

III, 6, 54, 4

III, $6,55,1$

III, $6,55,1$

III, $6,55,1$

III, $6,55,1$

III, $6,55,2$

III, $6,56,1$

III, $6,56,1$

III, 6, 56, 2

III, $6,56,2$

III, 6, 56, 3

III, $7,57,1$

III, $7,57,2$

III, 7, 57, 3

III, 7, 57, 3

III, 7, 58, 1

III, 7, 58, 2

III, 7, 59, 3

III, 7, 59, 4

III, 7, 59, 4

III, 7, 59, 4

III, 7, 60, 2-3

III, $8,61,1$

III, 8, 61, 2

III, 8, 62, 1

III, 8, 62, 2

III, 8, 62, 2-3

III, 8, 62, 3

III, 9, 63, 1-2
Col 2:18.23

1 Cor 7:27

1 Cor 7:2.5

$3 \mathrm{Kgdms} \mathrm{17:6}$

1 Kgdms 9:23-24

Rom 14:3

Matt 11:18-19

Phil 4:3 ?

1 Cor 9:5

1 Cor 7:35

1 Tim 5:9-10

Rom 14:17

3 Kgdms 19:13.19

Nicolaus, unknown fragment 2

Matt 5:42

Matt 25:35-36.40

Prov 19:17

Prov 3:27

Prov 3:3

Prov 10:4

Ps 14 (15):5

Ezek 18:8; Prov 13:8

Matt 19:19-20

Prov 13:11; 11:24

Ps 111 (112):9

Matt 6:19

Hag 1:6

Luke 12:16-20

Aristotle, Eth. Nic. $1151 \mathrm{b33}$

Matt 7:7

Exod 24:18

Philo, Vita Mois. II, 69

John 1:13

Rom 13:13-14

Valentinus, Fr. 3 (Markschies) = Epistula ad Agathopoda

1 Cor 3:16-17

Matt 19:12

Heb 9:14

Alexander Polyhistor, Indica, Fr. 18 (Jacoby) / 95 (Müller)

Rom 6:14

Rom 6:15

2 Cor 5:10

2 Cor 5:17

2 Cor 6:14-16

2 Cor $7: 1$

Gospel according to the Egyptians, Fr. B (Schneemelcher)
NT

NT

NT

$\mathrm{OT}$

OT

NT

NT

NT

NT

NT

NT

NT

OT

JAChrL

NT

NT

OT

OT

OT

OT

OT

OT

NT

OT

OT

NT

OT

NT

C

NT

OT

JAChrL

NT

NT

JAChrL

NT

NT

NT

C

NT

NT

NT

NT

NT

NT

JAChrL 
III, 9, 63, 3

III, 9, 64, 1

III, 9, 64, 2

III, 9, 65, 1

III, 9, 65, 2

III, 9, 66, 1-2

III, 9, 67, 2

III, $10,68,1$

III, $10,68,2$

III, 10, 68, 3

III, 10, 69, 2

III, 10, 69, 4

III, $10,70,2$

III, 11, 71, 3

III, $11,71,3$

III, 11, 71, 4

III, 11, 72, 2

III, 11, 72, 3

III, 11, 73, 1

III, 11, 73, 2

III, 11, 73, 3

III, 11, 74, 1

III, 11, 74, 1

III, 11, 74, 3

III, 11, 75, 1-2

III, 11, 75, 3

III, 11, 76, 1

III, 11, 76, 2

III, 11, 76, 3-77, 1

III, 11, 77, 2

III, 11, 77, 3

III, 11, 78, 1

III, 11, 78, 2-3

III, 11, 78, 4

III, 12, 79, 1

III, 12, 79, 2

III, 12, 79, 3

III, $12,79,6$

III, 12, 79, 7

III, $12,80,1$

III, $12,80,1$

III, $12,80,2$

III, $12,80,2$

III, 12, 80, 2

III, 12, 81, 1-2

III, 12, 81, 2
Eph 2:5

Gospel according to the Egyptians, Fr. C (Schneemelcher)

Rom 5:12.14

Gen 3:20

Phil 1:20-24

Gospel according to the Egyptians, Fr. D (Schneemelcher)

Ps 48 (49):13.21

Matt 18:20

1 Cor $7: 8$

Gospel according to the Egyptians, Fr. E (Schneemelcher)

Gen 12:3

Gen 1:26

Eph 2:15; 2 Cor 6:16

Exod 20:17

Matt 5:27-28

Deut 21:11-13

Exod 7:7

Num 3:39

Exod 19:15

2 Cor 6:16

2 Cor 6:17-18

2 Cor $7: 1$

2 Cor 11:2

2 Cor 11:3

1 Pet 2:11-12.15-16

Rom 6:2.6-13

Matt 5:27-28

Rom 7:7 (Exod 20:17)

Rom 7:17-24

Rom 8:2-4

Rom 8:10-11

Rom 8:5-8

Rom 8:9-10.12-14

Rom 8:15

1 Cor 7:5

1 Cor 7:36

Matt 19:12

1 Tim 3:4-5

1 Cor 7:22.24

Rom 7:2

1 Cor 7:39-40

Rom 7:4

2 Cor 11:3

Gen 3:20

Tatian, On Training Following the Savior, Fr. 5 (Whittaker)

Matt 6:24
NT

JAChrL

NT

$\mathrm{OT}$

NT

JAChrL

OT

NT

$\mathrm{NT}$

JAChrL

OT

OT

NT

OT

NT

$\mathrm{OT}$

OT

OT

OT

NT

NT

NT

NT

NT

NT

NT

NT

NT

NT

NT

NT

NT

NT

NT

NT

NT

NT

NT

NT

NT

NT

NT

NT

OT

JAChrL

NT 


\begin{tabular}{|c|c|c|c|}
\hline III, $12,81,2$ & 1 Cor $7: 5$ & NT & \\
\hline III, $12,81,5$ & Gen 4:25 & OT & \\
\hline III, $12,82,1$ & 1 Cor 7:5 & NT & \\
\hline III, $12,82,2$ & Tatian, On Training Following the Savior, Fr. 6 (Whittaker) & JAChrL & \\
\hline III, $12,82,3$ & Gen 1:28 & OT & \\
\hline III, $12,82,3$ & Gen 1:18 & OT & \\
\hline III, $12,82,4$ & 1 Cor 7:6ff. & NT & \\
\hline III, $12,82,5$ & 1 Cor $7: 35$ & NT & \\
\hline III, $12,82,6$ & Lev 15:18 & OT & \\
\hline III, $12,83,4$ & Matt 19:6 & NT & \\
\hline III, $12,83,5$ & Rom 7:14 & NT & \\
\hline III, $12,83,5$ & Rom 7:4 & NT & \\
\hline III, $12,84,1$ & Rom 7:12 & NT & \\
\hline III, $12,84,2$ & Eph 5:32 & NT & \\
\hline III, $12,84,3$ & John 3:6 & NT & \\
\hline III, $12,84,3$ & 1 Cor $7: 14$ & NT & \\
\hline III, $12,84,4$ & Rom 7:4 & NT & \\
\hline III, $12,85,1$ & $1 \operatorname{Tim} 4: 1-5$ & NT & \\
\hline III, $12,85,2$ & Rom 14:21 & NT & \\
\hline III, $12,85,2$ & 1 Cor $7: 8$ & NT & \\
\hline III, $12,86,1$ & 1 Cor 7:20.24 & NT & \\
\hline III, $12,86,2$ & Barn. 11, 9 & JAChrL & \\
\hline III, $12,86,3$ & Matt 6:19 & NT & \\
\hline III, $12,86,3$ & Isa $50: 9$ & OT & \\
\hline III, $12,87,1$ & John 6:27 & NT & \\
\hline III, $12,87,1$ & Luke 20:34-35 & NT & \\
\hline III, $12,87,4$ & Matt 23:9 & NT & $\stackrel{N}{N}$ \\
\hline III, $12,88,1$ & Matt 18:3 & NT & $\check{0}$ \\
\hline III, $12,88,1$ & John 3:5 & NT & 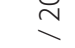 \\
\hline III, $12,88,2$ & 1 Cor 7:32-33 & NT & $\bar{\sim}$ \\
\hline III, $12,88,3$ & 1 Cor $7: 34$ & NT & . \\
\hline III, $12,88,4$ & 1 Cor $6: 18$ & NT & $\bar{c}$ \\
\hline III, 12, 89, 2 & Isa 50:1 & OT & $\stackrel{c}{5}$ \\
\hline III, $12,89,2$ & Bar 3:10 & OT & $\frac{2}{2}$ \\
\hline III, $12,89,3$ & 1 Tim 5:14-15 & NT & ๕ึ \\
\hline III, $12,90,1$ & $1 \operatorname{Tim} 3: 2.12$, aj. & NT & 敢 \\
\hline III, $12,90,2$ & Matt 12:39 & NT & '̀ \\
\hline III, $12,90,3$ & Bar 4:6 & OT & d \\
\hline III, $12,90,4$ & Luke $14: 20$ & NT & ப் \\
\hline III, $12,90,5$ & Ps $6: 8$ & OT & \\
\hline III, 13, 91, 1-92, 2 & John Cassian, On Self-Control or Celibacy (unknown fragment) & JAChrL & \\
\hline III, $13,91,2$ & Matt 19:12 & NT & \\
\hline III, $13,91,2$ & Isa $56: 3$ & OT & \\
\hline III, $13,92,2$ & Gospel according to the Egyptians, Fr. F (Schneemelcher) & JAChrL & \\
\hline III, $13,93,2$ & Gal 3:28 & NT & \\
\hline III, $14,94,1$ & 2 Cor $11: 3$ & NT & \\
\hline
\end{tabular}


III, 14, 94, 3

III, 14, 95, 1

III, $14,95,2$

III, 14, 95, 2

III, 14, 95, 3

III, 14, 95, 3

III, 14, 95, 3

III, $15,96,1$

III, $15,96,2$

III, $15,97,1$

III, $15,97,2$

III, $15,97,3$

III, $15,97,3$

III, 15, 97, 4

III, 15, 98, 1

III, 15, 98, 3

III, 15, 98, 4

III, 15, 99, 1

III, 15, 99, 1

III, 15, 99, 2

III, 15, 99, 2

III, 15, 99, 3

III, 15, 99, 4

III, 15, 99, 4

III, 16, 100, 1

III, 16, 100, 2

III, 16, 100, 3

III, 16, 100, 4

III, $16,100,7$

III, $16,100,7$

III, $16,101,1$

III, 16, 101, 2

III, 16, 101, 3

III, 16, 101, 3

III, 16, 101, 3

III, 16, 101, 4

III, 16, 101, 4

III, 17, 102, 3

III, 17, 102, 3

III, 17, 103, 2

III, 17, 103, 3

III, 17, 103, 4

III, 17, 104, 1-2

III, 17, 104, 5

III, $17,104,5$

III, $17,104,5$
Matt 5:28

Eph 4:24

Gen 3:21

Phil 3:20

Heb 11:13

1 Cor 7:29-31

1 Tim 4:4

1 Cor $7: 1-2.5$

1 Cor 7:5

1 Cor 7:9

Luke 14:26

Exod 20:12

1 Cor 7:33

Gospel according to the Egyptians, Fr. G (Schneemelcher) ?

Isa 56:3-5

Isa 65:23

1 Cor $4: 15$

Isa 56:2

Philo, De ebrietate 220.224

John 13:33

Gal 4:19

1 Cor 4:15

Deut 23:1

unknown Jesus' word

Jer 20:14

Jer 20:18

4 Ezra 5:35

Job 14:4-5

Ps 50 (51):7

Gen 3:20

Mic 6:7

Gen 1:28

3 Kgdms 15:34

Eph 6:12

1 Cor 7:5-6

1 Cor 9:27

1 Cor 9:25

Ps 48 (49): 13.21

Jer 5:8

Isa 40:6-8

Eph 1:22

Prov 13:12

Gen 4:1.17

1 Cor 15:50

2 Cor 5:21

Gal 3:3
NT

NT

$\mathrm{OT}$

NT

NT

NT

NT

NT

NT

NT

NT

OT

NT

JAChrL

OT

OT

NT

OT

JAChrL

NT

NT

NT

OT

JAChrL

OT

OT

OT

OT

OT

OT

OT

OT

OT

NT

NT

NT

NT

OT

OT

OT

NT

OT

OT

NT

NT

NT 


\begin{tabular}{|c|c|c|}
\hline III, 18, 105, 2 & Jer 5:8 & OT \\
\hline III, $18,105,2$ & Prov 1:14 & OT \\
\hline III, $18,106,1$ & Prov 1:15.17-18 & OT \\
\hline III, 18, 106, 2 & Eph 2:3 & NT \\
\hline III, $18,106,3$ & 1 Cor 5:7 & NT \\
\hline III, $18,106,3$ & 1 Cor 5:11 & NT \\
\hline III, $18,106,4$ & Gal 2:19-20 & NT \\
\hline III, $18,107,1$ & Matt 10:5 & NT \\
\hline III, $18,107,1$ & Prov 1:18-19 & OT \\
\hline III, 18, 107, 2 & 1Klem 46, 8 & JAChrL \\
\hline III, 18, 107, 2 & Rom 2:24 & NT \\
\hline III, $18,107,3$ & 1 Cor 5:9-6:13 & NT \\
\hline III, $18,107,4$ & 1 Cor $6: 16$ & NT \\
\hline III, $18,107,5$ & 1 Cor 7:5.3 & NT \\
\hline III, $18,108,1$ & Gen 2:18 & OT \\
\hline III, $18,108,1$ & 1 Cor $7: 10-14$ & NT \\
\hline III, $18,108,2$ & 1 Tim 3:2.4 (Tit 1:6) & NT \\
\hline III, $18,109,1$ & Tit $1: 15$ & NT \\
\hline III, 18, 109, 2 & 1 Cor 6:9-11 & NT \\
\hline III, 18, 109, 2 & Matt 8:12-13 & NT \\
\hline III, 18, 109, 3 & Phil 4:8-9 & NT \\
\hline III, $18,110,1-2$ & 1 Pet $1: 21-22.14-16$ & NT \\
\hline
\end{tabular}

